\title{
Improvement of Learning Outcomes by Direct Instruction (DI) Learning Model in General Chemistry Course
}

\author{
Gulmah Sugiharti ${ }^{1}$, Abdul Hamid ${ }^{2}$ and Mukhtar $^{3}$ \\ \{gulmahsugiharti@yahoo.com ${ }^{1}$, mukhtar.mt@gmail.com ${ }^{2}$ and abdhamid_k@yahoo.co.id ${ }^{3}$ \}
}

Department of Chemistry Education, Faculty of Mathematics and Natural Science, Universitas Negeri Medan, Medan, Indonesia ${ }^{1}$, Postgraduate Program, Universitas Negeri Medan, Department of Building Engineering, Faculty of Engineering, UniversitasNegeri Medan, Medan, Indonesia ${ }^{2}$ and Postgraduate Program, Universitas Negeri Medan, Department of Mathematics, Faculty of Mathematics and Natural Science, UniversitasNegeri Medan, Medan, Indonesia ${ }^{3}$

\begin{abstract}
The learning activities of General Chemistry course are still more dominated by lecturers by requiring students to do assignments and solve chemical concept questions. This led to a lack of understanding of students which resulted in low learning outcomes of general chemistry courses. Even though the concept can be related to students' daily lives by applying effective learning models in accordance with teaching materials. The purpose of this study was to determine whether there were significant differences in learning outcomes between the classes taught with PBL models and the classes taught in the DI model in the General Chemistry course at the Chemistry Education department of FMIPA Unimed. The population consists of 2 classes, each of which consists of 26 students taught with different learning models. After the data is tested normal and homogeneous by using SPSS, the hypothesis is tested using t test. Based on the results of the hypothesis test, it is known that the value of Sig. $0.065<0.10$. So it was said that there were significant differences in learning outcomes of classes taught with PBL models with classes taught with the DI model in General Chemistry courses. This study concludes that for the General Chemistry subject learning, it is better to use the PBL model than the DI model.
\end{abstract}

Keywords: PBL model, DI model, General Chemistry

\section{Introduction}

Improving human resources in Indonesia, for instance by renewal in the field of education, namely by improving the quality of educators and education personnel by taking advanced study programs that are relevant in domestic and abroad, conducting training and upgrading, implementing Tri Dharma PerguruanTinggi for lecturers, the existence of lecturer certification, Higher Education Accreditation and so on.

But the reality on the ground shows that educational achievement in Indonesia is still far below other Asian countries. Based on the United Nations Development Program (UNDP) report, it was seen that the 2013 HDI (Human Development Index) was ranked 121 of 187 countries. Whereas in 2015, it is still around the order of 108 out of 187 countries (UNDP, 2015). 
Chemistry studies about the composition, structure, properties, changes in material, and changing energy changes. Chemistry subject can be packaged more simply than it actually is. Learning especially chemistry lessons, teachers are required to have adequate ability in carrying out their learning activities and must be able to realize an effective learning environment and are better able to manage their class so that student learning achievement is high.

The 2012 results of the Program for International Student Assessment (PISA) show that the science scores achieved by Indonesian students are also still below the international average score, which is 382. This achievement ranks Indonesia 64th out of 65 participating countries (Pambudi, 2016). According to data from the Ministry of Education and Culture (Kemendikbud, 2016), Indonesia the average score of the National Chemistry Examination in 2014/2015 from 67,478 students is 77.90 where more than $20 \%$ of student scores are still below 70.00. This shows that there is still a need to increase the value of Chemistry learning in Indonesia.

in Unimed,the subjects which are closely related to the mastery of basic chemical materials are General Chemistry courses. From the profile data of the organizer of the subject education process with General Chemistry shows that the results of the General Chemistry course joint examination for the last 5 years are still low, where in each semester it does not reach $50 \%$ graduation (archive of chemistry education majors, 2016). The learning done so far is still dominated by lecturers and has not considered the learning model. In this study, in addition to the Direct Instructional (DI) model that has been commonly used, Problem Based Learning (PBL) learning models will be used.The use of the right learning model is one of the important things as a means of teaching and learning activities to convey knowledge to students and improve learning success (Assriyanto, 2014)

\section{Subject Of General Chemistry}

General Chemistry Courses are compulsory subjects for new students, Semester 1 and 2 at FMIPA Unimed. This is because this course is a joint subject that must be mastered to be able to achieve a bachelor's degree at FMIPA Unimed. During this time, learning activities are still dominated by lecturers by requiring students to work on tasks and solve chemical concept questions. Even though the concept can be related to students' daily lives by applying effective learning models in accordance with teaching materials. The use of the right learning model is one of the important things as a means of teaching and learning activities to convey knowledge to and improve learning success (Assriyanto, 2014)

Chemistry studies about the composition, structure, properties, changes in material, and changing energy changes. Chemistry subject can be packaged more simply than it actually is. Learning especially chemistry lessons, teachers are required to have adequate ability in carrying out their learning activities and must be able to realize an effective learning environment and are better able to manage their class so that student learning achievement is high.

Chemistry was born from the desire of chemists to get answers to what and why the nature of matter exists in nature, each of its will produce facts and theoretical knowledge about matter whose truth can be explained by mathematical logic. Some aspects of chemistry are visible which means that concrete facts can be made and some aspects are only abstract (invisible) meaning they are not proven by mathematical logic so that rationality can be 
formulated. Chemistry is defined as a science that studies the structure, composition, nature, and changes in material and energy that accompany these material changes (Ministry of National Education, 2003)

Chemistry as a process can mean all scientific activities to perfect knowledge and to find new knowledge. The chemistry learning process emphasizes giving direct experience to develop competencies so that students are able to explore and understand the natural environment in a scientific manner. Obtaining experience in applying the scientific method through experiments or experiments, where students test hypotheses by designing experiments through instrument installation, retrieval, processing and interpretation of data, and delivering experimental results orally and in writing, is a scientific process that must be carried out to obtain knowledge new ones for students. Limitations of tools and materials in chemical learning can be overcome by using a Virtual lab.

\section{Pbl Model And Di}

The learning process is an interaction of learning between teachers and students. While the problem in essence is a question that contains answers. So that problem-based learning is an interaction activity between the teacher and students by using questions that contain answers (Asra, 2013). Problem-based learning, later abbreviated PBL, is a learning model that involves students to solve a problem through the stages of the scientific method so that students can learn knowledge related to the problem and at the same time have the skills to solve problems (Ngalimun, 2014) Kivela (2005) describes a problem-based learning model as a learning model that can encourage students to learn independently and improve thinking skills. In short, it can be said that learning starts from one problem and solving problems is the goal of each lesson.

In PBL there is working group and discussion that requires students to interact with their friends so that new knowledge and skills arise. This knowledge is built through the process of asking questions, group work, discussion and debate when presenting their work, which requires thinking skills, which students can learn communicatively and effectively. In connection with this, Asra (2013) writes that problem solving ability requires a thought process. If the problem can be solved, the student learns something new. Therefore the ability of students to think needs to be improved. .

Direct Interaction teaching model later abbreviated as DI is a teaching model that is teacher center. According to Arends in Trianto (2014). Direct teaching model is one of the teaching approaches specifically designed to support student learning processes that are related to well-structured declarative knowledge and procedural knowledge that can be taught with a step-by-step, gradual activity pattern. In addition, direct learning models are also intended to help students learn basic skills and obtain information that can be taught step by step. Joyce, Weil (2011) wrote that the direct learning model begins with the teacher's explanation of new concepts or skills to students.

David (2009) explained that direct learning is learning that is designed to teach knowledge and basic skills that students need for subsequent learning. Direct learning is very useful especially when there are skills that can be mapped into specific steps. Direct learning steps emphasize the role of educators and activate the role of students to build concepts in students. In this case learning should use a variety of appropriate media, such as films, pictures, demonstrations, as well as virtual labs 


\section{Virtual Lab}

Virtual lab is a form of learning media by using a laboratory to make observations or experiments through software run by a computer, where all the equipment needed by a laboratory is contained in the software (Eko, 2014). There are two main concepts of computer laboratories (Tyder, 2008), namely real estate computer replacements so that experiments take place in the form of virtual animation or experimentation, and laboratory experiments are described as virtual when experiments are not controlled by direct manipulation of laboratory equipment but with computer equipment. Virtual laboratories provide many benefits that are very useful as a medium to teach safe and cheap, effective to teach abstract concepts that are difficult to understand to overcome the lack of facilities, tools and materials in the laboratory, the expensive tools and chemicals can be overcome with the help of computers.

\section{Research Methodology}

This research was carried out in 2018 at the Chemistry Education Study Program at FMIPA Unimed. The population in this study were all students of chemistry education study programs who were taking course of General Chemistry which amounts to 4 classes. The class sample was determined as much as 2 classes from 4 classes that were available in the Chemistry Education study program by random sampling. While the research sample consisted of 26 students in each class.

Data Analysis Technique uses descriptive analysis to describe the data, including: average value (mean), median, standard deviation (SD) and data tendency using the SPSS program.

Analysis requirements test used in the form of normality test (NPar Tests), with OneSample Kolmogorov-Sminov Test and homogeneity test using the Oneway Test of Homogeneity of Variances. While to see whether there is a difference in student learning outcomes, the $t$ test is used.

Testing criteria are:

Reject $\mathrm{H} 0$, if $\mathrm{t}$ counts> t table

\section{Research Result And Discussion}

Table 1. Student Learning Outcomes Data.

\begin{tabular}{ccc}
\hline No. & A1 & A2 \\
\hline 1 & 90 & 80 \\
2 & 87.5 & 77.5 \\
3 & 85 & 77.5 \\
4 & 82.5 & 75 \\
5 & 82.5 & 75 \\
6 & 80 & 72.5 \\
7 & 80 & 72.5 \\
8 & 77.5 & 72.5 \\
9 & 77.5 & 70 \\
10 & 75 & 67.5
\end{tabular}




\begin{tabular}{ccc}
\hline No. & A1 & A2 \\
\hline 11 & 75 & 65 \\
12 & 72.5 & 65 \\
13 & 70 & 62.5 \\
14 & 80 & 80 \\
15 & 77.5 & 80 \\
16 & 77.5 & 77.5 \\
17 & 75 & 75 \\
18 & 72.5 & 75 \\
19 & 70 & 72.5 \\
20 & 72.5 & 72.5 \\
21 & 70 & 70 \\
22 & 70 & 70 \\
23 & 67.5 & 67.5 \\
24 & 65 & 67.5 \\
25 & 62.5 & 65 \\
26 & 60 & 62.5 \\
SUM & 1955 & 1867.5 \\
MEAN & 75.2 & 71.8
\end{tabular}

Note :

$\mathrm{A} 1=$ Group of student taught by PBL model

$\mathrm{A} 2=$ Group of student taught by DI model

Table 2. Normality Test N Par Test.

\begin{tabular}{|c|c|c|c|}
\hline \multicolumn{4}{|c|}{ One-Sample Kolmogorov-Smirnov Test } \\
\hline & & $\mathrm{A} 1$ & $\mathrm{~A} 2$ \\
\hline \multirow{5}{*}{$\begin{array}{l}\mathbf{N} \\
\text { Normal } \\
\text { Parameters }^{\mathrm{a}, \mathrm{b}}\end{array}$} & & 26 & 26 \\
\hline & Mean & 75.1 & 71.8 \\
\hline & & 923 & 269 \\
\hline & Std. & 7.34 & 5.36 \\
\hline & Deviatio & 585 & 459 \\
\hline \multirow{3}{*}{$\begin{array}{l}\text { Most Extreme } \\
\text { Differences }\end{array}$} & Absolute & .086 & .127 \\
\hline & Positive & .069 & .098 \\
\hline & $\begin{array}{l}\text { Negativ } \\
\mathrm{e}\end{array}$ & -.086 & -.127 \\
\hline \multicolumn{2}{|c|}{$\begin{array}{l}\text { Test Statistic } \\
\text { Asymp. Sig. (2-tailed) }\end{array}$} & $\begin{array}{r}.086 \\
.200^{\mathrm{c}} \\
, \mathrm{d}\end{array}$ & $\begin{array}{r}.127 \\
.200^{\mathrm{c}} \\
\text {, d }\end{array}$ \\
\hline \multicolumn{4}{|c|}{$\begin{array}{l}\text { a. Test distribution is Normal. } \\
\text { b. Calculated from data. } \\
\text { c. Lilliefors Significance Correction. } \\
\text { d. This is a lower bound of the true } \\
\text { significance. }\end{array}$} \\
\hline
\end{tabular}

Based on result of Normality test Kolmogorov Smirnov, known that value of Sig. Class A1 and A2 >005. Therefore if Sig > 0.05, data is normally distributed, so can be concluded that distribution of postest outcome Class A1 and A2 are normal. 


\section{Homogenity Test}

Table 3. Normality Test N Par Test.

\begin{tabular}{cccc}
\hline \multicolumn{5}{c}{ Model } \\
\hline Levene Statistic & df1 & df2 & Sig. \\
\hline 1.730 & 1 & 50 & $\mathbf{. 1 9 4}$
\end{tabular}

Table 4. Anova

\begin{tabular}{lcccrr}
\hline Model & Sum of & d & Mean & F & S \\
& Squares & f & Square & & i \\
& & & & & g \\
& & & & & . \\
& & & 147.23 & 3. & . \\
Between & 147.236 & 1 & 6 & 55 & 0 \\
Groups & & & & 9 & 6 \\
& & & & & 5 \\
Within & 2068.510 & 5 & 41.370 & & \\
Groups & & 0 & & & \\
Total & 2215.745 & 5 & & & \\
& & 1 & & & \\
\hline
\end{tabular}

Based on result of Normality test Kolmogorov Smirnov, known that value of Sig. Class A1 and A2 > 005. Therefore if Sig > 0.05, data is normally distributed, so can be concluded that distribution of postest outcome Class A1 and A2 are normal.

Table 5. Hypotesis Test of T-Test

\begin{tabular}{|c|c|c|c|c|c|}
\hline \multicolumn{6}{|c|}{ Group Statistics } \\
\hline \multirow{5}{*}{ Model } & Kelas & $\mathrm{N}$ & Mean & $\begin{array}{c}\text { Std. } \\
\text { Deviation }\end{array}$ & $\begin{array}{l}\text { Std. Error } \\
\text { Mean }\end{array}$ \\
\hline & Kelas & 2 & 75.192 & 7.34585 & 1.44064 \\
\hline & PBL & 6 & 3 & & \\
\hline & Kelas & 2 & 71.826 & 5.36459 & 1.05208 \\
\hline & DI & 6 & 9 & & \\
\hline
\end{tabular}

\section{Conclusion}

This research conclude that study the course of General Chemistry is better to use learning model of PBL than learning model DI, where the outcomes of study the student using PBL model higher than DI model. 
Acknowledgements. Acknowledgments to DRPM DIKTI for the support of the doctor's dissertation research (PDD) and the Unimed Leader who has given me permission to study permit.

\section{References}

[1] Arsip jurusan kimia, daftar perolehan nilai ujian bersama prodi pendidikan kimia.

[2] Asra, Sumiati.: Metode Pembelajaran. CV Wacana Prima, Bandung (2013)

[3] Assriyanto,K.E.,Sukardjo,J.S. Sulistyo,S.: Pengaruh Model Pembelajaran Berbasis Masalah Melalui Metode Eksperimen Dan Inkuiri Terbimbing Ditinjau Dari Kreativitas Siswa Pada MateriLarutan Penyangga, Jurnal Pendidikan Kimia (JPK), 3 (3) : 90-91. (2014)

[4] Dalgamo, B, Bishop,A.G.,\& Bedgood,D.R.: Develoving an Interactive Virtual Chemistry Laboratory enriched with ContructivistLearning Activities forScondary Schools. Journal of Chemical Education, 82: 853-865 (2009)

[5] David A. Jacubsens. Paul Egen.: Methode for Teaching. Pustaka Pelajar, Yogyakarta (2009)

[6] Eko S., Leny, Y.: Penerapan Media Laboratorium Virtual (PhET) Pada Materi Laju Reaksi dengan Model Pengajaran Langsung, Surabaya :Jurnal Pendidikan Kimia, FMIPA, Universitas Negeri Surabaya (2014)

[7] Sugiharti. Gulmah.: Perbaikan Pembelajaran Matakuliah Evaluasi dan PHB Kimia Dengan Model Pembelajaran Interaktif di Jurusan Kimia Fmipa-Unimed. Laporan Teaching Grant. PHKI Batch I tahun 2010. FMIPA Unimed (2010)

[8] Joyce,. Bruce \& Weill,.M.: Models of Teaching.Model-model Pengajaran, Yogjakarta : Pustaka Pelajar, 2011

Kivela, Student Perceptions of an embedded problem-based learning instructional approach in a hospitality undergraduate program, International Journal Of Hospitality Management, 24 (3) : 437 464. (2005)

[9] Ngalimun, S.: Strategi dan Model Pembelajaran, Jakarta :Aswaja Pressindo (2014)

[10] Motaz, A.: Start programming using Object Pascal. Vol. 2, pp. 10-11. Legally Free Computer Books, US (2013)

[11] Tyder J.: An online virtual laboratory of electricity International Jurnals of Distance Education Technologies 6(2) : 21-23 (2008)

[12] UNDP, Human Development Index and its component Tabel 1( diakses tanggal 15 Februari 2016) 